Bull. Chem. Soc. Ethiop. 2021, 35(1), 141-150.

(C) 2021 Chemical Society of Ethiopia and The Authors

ISSN 1011-3924

DOI: https://dx.doi.org/10.4314/bcse.v35i1.12

Printed in Ethiopia

Online ISSN 1726-801X

\title{
PHYTOCHEMICAL STUDIES OF MELILOTUS OFFICINALIS
}

\author{
Melaku Assefa Sisay, Wendimagegn Mammo, Estifanos Ele Yaya* \\ Department of Chemistry, Addis Ababa University, P.O. Box 1176, Addis Ababa, Ethiopia
}

(Received November 24, 2020; Revised April 6, 2021; Accepted April 7, 2021)

\begin{abstract}
GC-MS analysis of the $n$-hexane extract of Melilotus officinalis seeds revealed twelve compounds with a combined area percentage of $98.33 \%$ predominantly, $(9 Z, 12 Z)$-octadecadienoic acid $(20.22 \%, 366 \mathrm{ppm})$, 14-methylpentadecanoic acid $(19.52 \%, 353 \mathrm{ppm})$ and $(9 E)$-octadecenoic acid $(15.94 \%, 289 \mathrm{ppm})$. Two compounds, namely, cis-coumaric acid-2-O- $\beta$-D-glucopyranoside (cis-melilotoside, 1) and 1,2-benzopyrone (coumarin, 2), were isolated from the $\mathrm{MeOH}$ extract of the seeds of $M$. officinalis. The structures of isolated compounds were determined by spectroscopic techniques such as NMR, UV-Vis, and FTIR. The MeOH extract of M. Officinalis was also tested for its antioxidant activity using DPPH assay. The extract showed $29.87 \%$ DPPH inhibition at concentration of $100 \mu \mathrm{g} / \mathrm{mL}$.
\end{abstract}

KEY WORDS: Melilotus officinalis, Fatty acid methyl esters, Esterification, GC-MS, DPPH radical scavenging assay, Antioxidant activity

\section{INTRODUCTION}

Melilotus officinalis belongs to the family Leguminosae (Fabaceae), and is an annual erect often more than $1 \mathrm{~m}$ tall with small yellow flowers [1]. It is commonly known as yellow sweet clover or medicinal sweet clover [2]. It is widely distributed around the world and occurs in most parts of Ethiopia, Tanzania, North Asia and India [1]. M. officinalis is used not only as food and forage but also as a medicine. M. officinalis has been used for the treatment of arthritis, brachialgia, bronchitis, hemorrhoids, rheumatism, painful menstruation, palpitations, and kidney stones $[3,4]$.

This plant showed anti-inflammatory [5], antioxidant [6, 7], hepatoprotective [8], anxiolytic [9] and antiproliferative [10] effects and has also been reported to promote tissue regeneration, prevent skin aging, and reduce fat deposition [11]. Traditionally M. officinalis is used to treat inflammation, vitiligo and arteritis. M. officinalis was reported to contain uric acid, flavonoids and their glycosides, steroids and saponins, fatty acids, triterpenes, oleanane-type triterpeneglucuronides, phenolic acids, and volatile components [2, 4,1 2-25]. So far there is no detailed analysis made on the chemical composition of the plant seeds. Therefore, we have investigated the chemical compositions of the $n$-hexane and $\mathrm{MeOH}$ extracts of $M$. officinalis seeds.

\section{EXPERIMENTAL}

General experimental procedures

UV-Vis and FTIR spectra were determined using a UV-T60 spectrophotometer and a PerkinElmer Spectrum 65 instrument in the range $4000-200 \mathrm{~cm}^{-1}$, respectively. Gas chromatographymass spectrometry (GC-MS) experiments were conducted on Agilent Technologies 7820A GC system coupled with Agilent Technologies 5977E MSD, USA. ${ }^{1} \mathrm{H}-$ and ${ }^{13} \mathrm{C}-\mathrm{NMR}$ spectra were recorded on a Bruker Avance $400 \mathrm{NMR}$ spectrometer at 400.13 and $100.6 \mathrm{MHz}$, respectively. Column chromatography was performed using Sephadex LH-20 (GE Healthcare Bio-Sciences AB, Sweden). Preparative thin-layer chromatography (PTLC) was carried on acid washed silica

*Corresponding author. E-mail: estifanose.ele@aau.edu.et

This work is licensed under the Creative Commons Attribution 4.0 International License 
gel with $254 \mathrm{~nm}$ fluorescent indicator (Sigma-Aldrich, Germany) pre-coated on glass $(20 \times 20$ $\mathrm{cm})$. Thin-layer chromatography (TLC) was performed with Merck Kieselgel 60 F254 plates which were visualized under UV light and by spraying with vanillin, $\mathrm{H}_{2} \mathrm{SO}_{4}(5 \%)$ in $\mathrm{MeOH}$, and cerium molybdate stain ( $12 \mathrm{~g}$ ammonium molybdate, $0.5 \mathrm{~g}$ ceric ammonium molybdate, and 15 $\mathrm{mL}$ of concentrated $\mathrm{H}_{2} \mathrm{SO}_{4}$ in $235 \mathrm{~mL}$ of distilled water) followed by heating for a few seconds.

\section{Plant material}

M. officinalis was grown in the garden of Chemistry Department, Addis Ababa University, Addis Ababa, Ethiopia. A voucher specimen (No. Mel-003) was identified and deposited at the National Herbarium, Addis Ababa University, Addis Ababa, Ethiopia.

\section{Extraction of M. officinalis seeds}

The dried and ground seeds of M. officinalis (100 g) was Soxhlet-extracted with $n$-hexane (300 $\mathrm{mL})$ for $8 \mathrm{~h}$. The $n$-hexane was removed under reduced pressure to yield a yellow oil $(2.12 \mathrm{~g})$. The residue left after $n$-hexane extraction was further extracted with methanol $(300 \mathrm{~mL})$ for another $8 \mathrm{~h}$ and the methanol was removed under reduced pressure to yield a brown residue $(9.32 \mathrm{~g})$.

\section{Preparation of fatty acid methyl esters}

The $n$-hexane extract of $M$. officinalis seeds $(0.5 \mathrm{~g})$ was placed in a $50 \mathrm{~mL}$ round bottom flask fitted with a condenser and $2 \%$ methanolic $\mathrm{KOH}(3.0 \mathrm{~mL})$ was added. The mixture was heated at $50{ }^{\circ} \mathrm{C}$ for $30 \mathrm{~min}$ on a water bath with continuous shaking. The reaction mixture was cooled to room temperature and transferred to a separatory funnel. Saturated sodium chloride $(1 \mathrm{~mL})$ was added, and the mixture was extracted with petroleum ether $(15 \mathrm{~mL})$. The organic layer was separated, dried over anhydrous sodium sulfate, filtered, and concentrated to yield the esterified product $(150.9 \mathrm{mg})$.

\section{Preparation of methyl palmitate standard}

Methyl palmitate was prepared by Fischer esterification [26] of palmitic acid. Thus, in a $50 \mathrm{~mL}$ round bottom flask equipped with a reflux condenser, palmitic acid $(1 \mathrm{~g})$ was dissolved in $\mathrm{MeOH}(10 \mathrm{~mL})$ and then concentrated $\mathrm{H}_{2} \mathrm{SO}_{4}(1 \mathrm{~mL})$ was carefully added. The mixture was heated on a water bath at $50{ }^{\circ} \mathrm{C}$ for $1 \mathrm{~h}$ and then cooled to room temperature. Chloroform (30 $\mathrm{mL}$ ) was added, and the mixture was transferred to a separatory funnel and washed with deionized water $(30 \mathrm{~mL})$. The organic layer was then washed with aqueous $\mathrm{NaHCO}_{3}(30 \mathrm{~mL})$ and water $(30 \mathrm{~mL})$, dried over anhydrous sodium sulfate, filtered, and concentrated to afford methyl palmitate. Standard solutions of methyl palmitate were prepared at concentrations of 1 , $10,25,50$ and $100 \mathrm{ppm}$ and analyzed by GC-MS in triplicates.

\section{GC-MS analysis}

GC-MS analysis was conducted on an Agilent Technology 7820A GC system coupled with an Agilent Technology 5977E MSD equipped with an autosampler. The chromatographic separation was done on a DB-1701 (14\%-cyanopropyl-phenyl-methylpolysiloxane) column (30 $\mathrm{m} \times 0.25 \mu \mathrm{m})$ at a pressure of $8 \mathrm{psi}$ and a flow rate of $0.97989 \mathrm{~mL} / \mathrm{min}$. Ultra-high pure helium (99.999\%) was used as carrier gas at constant flow mode. An Agilent G4567A autosampler was used to inject $1 \mu \mathrm{L}$ of the sample with a splitless injection mode into the inlet heated to $275^{\circ} \mathrm{C}$ with a total run time of $29.33 \mathrm{~min}$. Oven temperature was programmed with the initial column temperature of $60^{\circ} \mathrm{C}$ and hold-time $2 \mathrm{~min}$. The column temperature was increased to $200^{\circ} \mathrm{C}$ at a rate of $10^{\circ} \mathrm{C} / \mathrm{min}$ and then heated again at a rate of $3{ }^{\circ} \mathrm{C} / \mathrm{min}$ until the temperature reached 240 
${ }^{\circ} \mathrm{C}$. No mass spectra were collected during the first 4 min of the solvent delay. The transfer line and the ion source temperatures were $280^{\circ} \mathrm{C}$ and $230{ }^{\circ} \mathrm{C}$, respectively. The detector voltage was $1600 \mathrm{~V}$ and the electron energy was $70 \mathrm{eV}$. Mass spectral data were collected from 40-650 m/z. The fatty acid methyl esters were identified by matching their mass spectra with those of reference compounds recorded in National Institute of Standards and Technology (NIST) mass spectral library.

\section{DPPH radical scavenging assay}

DPPH radical scavenging assay is a simple method for quantifying antioxidants by measuring absorbance at $517 \mathrm{~nm}$ due to the stable 2,2-diphenyl-1-picrylhydrazyl (DPPH) radical [27]. The DPPH radical scavenging assay of the $\mathrm{MeOH}$ extract of the seeds of $M$. officinalis was assessed according to the procedure described by Hoque et al. [28]. The MeOH extract $(1 \mathrm{mg})$ was first dissolved in $\mathrm{MeOH}(1 \mathrm{~mL})$. Seven different concentrations, 500, 250, 125, 62.50, 31.25, 15.63 and $7.81 \mu \mathrm{g} / \mathrm{mL}$, of the extract were prepared by diluting the stock solution $(1 \mathrm{mg} / \mathrm{mL})$ with $\mathrm{MeOH}$. To $1 \mathrm{~mL}$ of each solution, $0.004 \% \mathrm{DPPH}$ in $\mathrm{MeOH}(4 \mathrm{~mL})$ was added to make 100 , $50.00,25.00,12.50,6.25,3.13$ and $1.56 \mu \mathrm{g} / \mathrm{mL}$ solutions. The mixtures were shaken and left at room temperature for $30 \mathrm{~min}$. The absorbances of the solutions were then recorded at $517 \mathrm{~nm}$ using a UV-Vis spectrophotometer. All measurements were performed in triplicates and the same procedure was used to determine the radical scavenging activity of ascorbic acid standards.

\section{Isolation of compounds from the MeOH extract of $M$. officinalis seeds}

The $\mathrm{MeOH}$ extract $(2 \mathrm{~g})$ of $M$. officinalis was first dissolved in acetone $(100 \mathrm{~mL})$ to obtain the acetone-insoluble fraction $(125 \mathrm{mg})$. The acetone insoluble material $(50 \mathrm{mg})$ was subjected to column chromatography over Sephadex LH-20 using $\mathrm{CHCl}_{3}: \mathrm{MeOH}(2: 1)$ as eluent to yield compound 1 (12 mg). Another $2 \mathrm{~g}$ of the $\mathrm{MeOH}$ extract was dissolved in $\mathrm{MeOH}: \mathrm{H}_{2} \mathrm{O}$ (1:1) (200 $\mathrm{mL}$ ) and then extracted with ethyl acetate $(300 \mathrm{~mL})$. Removal of the solvent under reduced pressure afforded a gummy residue $(650 \mathrm{mg})$. The ethyl acetate-soluble fraction $(55 \mathrm{mg})$ was purified by PTLC using petroleum ether:ethyl acetate (9:1) as eluent to yield compound 2 (15.8 $\mathrm{mg}$ ) (Figure 2).

Cis-coumaric acid-2-O- $\beta$-D-glucopyranoside (cis-melilotoside) (1). White crystals, m.p. 126-127 ${ }^{\circ} \mathrm{C}$, Lit. [29] m.p. $128^{\circ} \mathrm{C}$; UV $\left(\mathrm{MeOH}, \lambda_{\max }, \mathrm{nm}\right): 261 ; \mathrm{IR}_{\mathrm{v}}\left(\mathrm{KBr}, \mathrm{cm}^{-1}\right): 3391,2926$, $1691,1636,1488,1455,1240,1075 ;{ }^{1} \mathrm{H}-$ and ${ }^{13} \mathrm{C}-\mathrm{NMR}$ data (Table 4) [30, 31].

1,2-Benzopyrone (coumarin) (2). White powder, m.p. 70-71 ${ }^{\circ} \mathrm{C}$, Lit. [32] m.p. 70-72 ${ }^{\circ} \mathrm{C}$; UV $\left(\mathrm{MeOH}, \lambda_{\max }, \mathrm{nm}\right): 274 ; \mathrm{IR}_{v}\left(\mathrm{KBr}, \mathrm{cm}^{-1}\right): 2959,2928,2857,1729,1288,1124 ;{ }^{1} \mathrm{H}-$ and ${ }^{13} \mathrm{C}-$ NMR data (Table 5) [32].

\section{RESULTS AND DISCUSSION}

\section{Characterization of seed fatty acids of M. officinalis}

The fatty acid methyl esters that were obtained by esterification of the $n$-hexane extract of $M$. officinalis seeds were subjected to GC-MS analysis. Quantifications of components in the $n$ hexane extract were made by using their relative area percentages. Methyl palmitate external standards were used to determine the concentrations ( $\mathrm{ppm}$ ) of the components. Thus, standard solutions of methyl palmitate were prepared and analyzed by GC-MS in triplicates at concentrations of $1,10,25,50$ and $100 \mathrm{ppm}$ (Table 1). Using the mean area of each concentration the calibration curve shown in Figure 1 was constructed and then used to calculate the concentrations (ppm) of the different components. 
Table 1. Methyl palmitate standard solutions and their corresponding areas.

\begin{tabular}{|c|c|c|}
\hline Concentration $(\mathrm{ppm})$ & Rt $(\mathrm{min})$ & Average area \\
\hline 1 & 14.946 & 36486415 \\
\hline 10 & 14.96 & 201524238 \\
\hline 25 & 14.960 & 367682433 \\
\hline 50 & 14.986 & 632297811 \\
\hline 100 & 15.013 & 1157940017 \\
\hline
\end{tabular}

$\mathrm{Rt}=$ retention time $(\mathrm{min}), \mathrm{ppm}=$ parts per million.

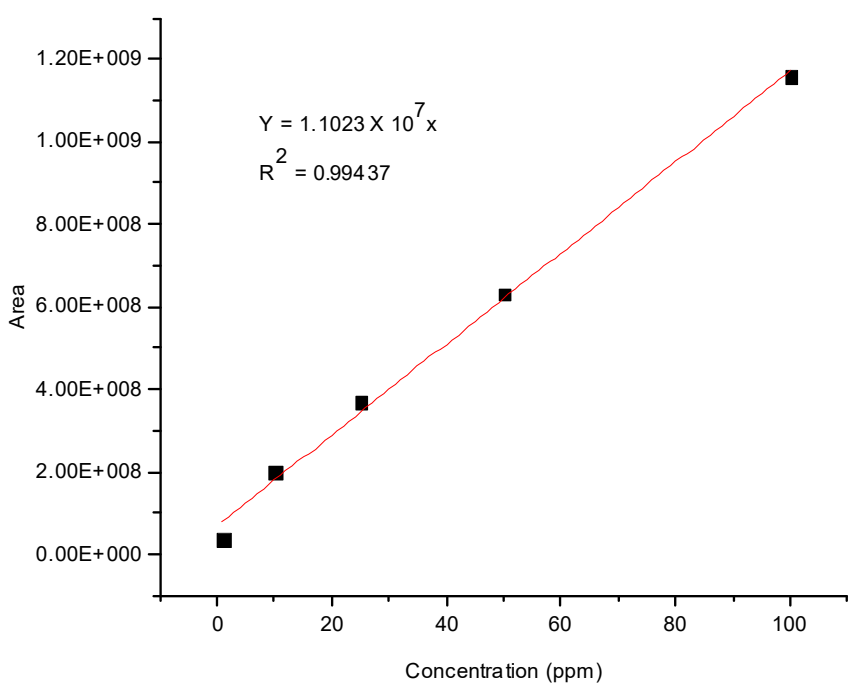

Figure 1. Calibration curve of methyl palmitate standard.

GC-MS analysis revealed the presence of 12 compounds with a combined area percentage of $98.33 \%$ (Table 2) including coumarin $(8.40 \%), 10$ fatty acids $(87.74 \%)$, and 5-dodecyldihydrofuran-2(3H)-one $(2.19 \%)$ with qualities greater than $90 \%$ and area percentage greater than 1. For identification of individual components in the extract, NIST 2014 mass spectral library search was used. The names of identified compounds with their respective retention times, area percentages, qualities and concentrations are given in Table 2.

It is apparent from Table 2 that the $n$-hexane extract of the seeds of M. Officinalis is mainly composed of unsaturated fatty acids (UFAs) and polyunsaturated fatty acids (PUFAs). In addition, the extract was found to be rich in $(9 Z, 12 Z)$-octadecadienoic acid $(20.22 \%, 366 \mathrm{ppm})$, 14-methylpentadecanoic acid $(19.52 \%, 353 \mathrm{ppm})$ and $(9 E)$-octadecenoic acid $(15.94 \%, 289$ ppm). The presence of unsaturated fatty acids in the seeds of Melilotus species, M. alba and $M$. officinalis, was previously reported using gas chromatography and flame ionization analysis [23].

\section{DPPH assay}

Radical scavenging activity was quantified by the decrease in absorbance of seven different concentrations of the $\mathrm{MeOH}$ extract of $M$. officinalis seeds in DPPH solution (0.004\%) [28]. Antioxidant activity of each concentration was measured in relation to ascorbic acid (a known 
antioxidant) standards. All determinations were performed in triplicates and percent DPPH inhibition was calculated as

$$
\% \text { DPPH inhibition }=\frac{A_{\text {control }}-A_{\text {extract }}}{A_{\text {control }}} \times 100
$$

where $A_{\text {control }}$ is the absorbance of DPPH solution without the test sample and $A_{\text {extract }}$ is the absorbance of the test sample plus DPPH.

Table 2. Major compounds identified from the n-hexane extract of M. officinalis seeds by GC-MS analysis.

\begin{tabular}{|c|c|c|l|c|c|}
\hline $\mathrm{Pk}$ & $\mathrm{Rt}$ & Area \% & Compound names & $\mathrm{Q}$ & $\mathrm{C}(\mathrm{ppm})$ \\
\hline 1 & 15.24 & 8.40 & Coumarin & 95 & 152 \\
\hline 2 & 18.96 & 19.52 & 14-Methylpentadecanoic acid & 95 & 353 \\
\hline 3 & 21.12 & 3.41 & Palmitic acid & 99 & 61.8 \\
\hline 4 & 21.99 & 15.94 & $(9 E)$-Octadecenoic acid & 99 & 289 \\
\hline 5 & 22.09 & 20.22 & (9Z,12Z)-Octadecadienoic acid & 99 & 366 \\
\hline 6 & 22.24 & 8.24 & Octadecanoic acid & 99 & 149 \\
\hline 7 & 22.38 & 1.95 & Linolenic acid & 99 & 35.4 \\
\hline 8 & 24.67 & 4.39 & Oleic acid & 99 & 79.5 \\
\hline 9 & 24.80 & 10.50 & Linoleic acid & 99 & 190 \\
\hline 10 & 25.05 & 2.19 & $\begin{array}{l}\text { 5-Dodecyldihydrofuran- } \\
\text { 2(3H)-one }\end{array}$ & 94 & 39.6 \\
\hline 11 & 25.21 & 1.85 & Eicosanoic acid & 99 & 33.4 \\
\hline 12 & 26.17 & 1.72 & 18-Methylnonadecanoic acid & 99 & 31.2 \\
\hline
\end{tabular}

$\mathrm{Pk}=$ peak number, $\mathrm{Rt}=$ retention time $(\mathrm{min}), \mathrm{Q}=$ quality, $\mathrm{C}=$ concentration.

The $\mathrm{MeOH}$ fraction of the seeds of $M$. officinalis was able to reduce the stable DPPH radical indicating its potential as a radical scavenger. The extract showed $29.87 \%$ DPPH inhibition at concentration of $100 \mu \mathrm{g} / \mathrm{mL}$ (Table 3).

Table 3. Radical scavenging activities of the methanol extract of M. officinalis seeds.

\begin{tabular}{|c|c|c|}
\hline \multirow{2}{*}{ Concentration $(\mu \mathrm{g} / \mathrm{mL})$} & \multicolumn{2}{|c|}{ \% DPPH inhibition } \\
\cline { 2 - 3 } & MeOH extract of M. officinalis & Ascorbic acid standard \\
\hline 100.00 & $29.87 \pm 0.49$ & $96.09 \pm 0.16$ \\
\hline 50.00 & $26.35 \pm 0.54$ & $96.29 \pm 0.06$ \\
\hline 25.00 & $24.82 \pm 0.23$ & $96.26 \pm 0.06$ \\
\hline 12.50 & $24.16 \pm 0.16$ & $96.06 \pm 0.12$ \\
\hline 6.25 & $22.12 \pm 0.91$ & $91.30 \pm 0.31$ \\
\hline 3.13 & $21.62 \pm 0.13$ & $54.06 \pm 1.27$ \\
\hline 1.56 & $21.53 \pm 0.12$ & $35.00 \pm 0.52$ \\
\hline
\end{tabular}

The results are reported as mean $\pm \mathrm{SD}$ of three replicates.

\section{Characterization of compounds isolated from $\mathrm{MeOH}$ extract of $\mathrm{M}$. officinalis seeds}

Compound 1 was obtained as white crystals and had a melting point of $126-127{ }^{\circ} \mathrm{C}$. The UVVis spectrum of $\mathbf{1}$ in $\mathrm{MeOH}$ displayed an absorption maximum $\left(\lambda_{\max }\right)$ at $261 \mathrm{~nm}$ which is characteristic of a phenolic moiety. The IR spectrum (KBr) indicated the presence of a carbonyl $\left(1691 \mathrm{~cm}^{-1}\right)$, aromatic $\left(1636,1240 \mathrm{~cm}^{-1}\right)$ and hydroxyl $\left(3391 \mathrm{~cm}^{-1}\right)$ functionalities. The ${ }^{1} \mathrm{H}-$ NMR data of 1 (Table 4) showed two olefinic hydrogen signals at $\delta 7.09(d, J=12.0 \mathrm{~Hz}, 1 \mathrm{H}, \mathrm{H}-$ 7) and $6.05(d, J=12.0 \mathrm{~Hz}, 1 \mathrm{H}, \mathrm{H}-8)$, which indicated the presence a cis double bond [30]. Besides, the coupling patterns of the aromatic proton signals at $\delta 7.12(d, J=8.0 \mathrm{~Hz}, 1 \mathrm{H}, \mathrm{H}-3)$, $7.30(d, J=8.0 \mathrm{~Hz}, 1 \mathrm{H}, \mathrm{H}-4), 7.03(t, J=8.0 \mathrm{~Hz}, 1 \mathrm{H}, \mathrm{H}-5)$ and $7.34(d, J=8.0 \mathrm{~Hz}, 1 \mathrm{H}, \mathrm{H}-6)$ 
suggested the presence of an ortho-substituted benzene ring. Additionally, the ${ }^{13} \mathrm{C}$-NMR spectrum (Table 4$)$ indicated the presence of a carbonyl carbon $(\delta 171.74)$, six aromatic and two olefinic carbon atoms. The signal at $\delta 153.81$ is due to an oxygenated aromatic carbon atom. The HMBC spectrum of 1 revealed a correlation between the signal at $\delta 125.53(\mathrm{C}-1)$ and the proton signals at $\delta 7.09(\mathrm{H}-7)$ and $6.05(\mathrm{H}-8)$. Thus, the olefinic carbon $\mathrm{C}-7$ ( $\delta$ 137.14) is attached to $\mathrm{C}-1$.

The presence of a glucopyranosyl ring in the structure of $\mathbf{1}$ was indicated by the analysis of its ${ }^{1} \mathrm{H}$-NMR spectrum together with its ${ }^{13} \mathrm{C}$-NMR spectrum. The glucose moiety, which can be assigned a $\beta$-configuration on the basis of the coupling constant of the anomeric proton at $\delta 5.05$ $\left(d, J=7.2 \mathrm{~Hz}, 1 \mathrm{H}, \mathrm{H}-1^{\prime}\right)[33]$ is attached to the $\mathrm{C}-2(\delta 153.81)$ position. Based on the analysis of the spectroscopic data and literature data, it can be concluded that compound $\mathbf{1}$ is cis-coumaric acid-2-O- $\beta$-D-glucopyranoside (cis-melilotoside, Figure 2) [30, 31]. This is the first report on the isolation of cis-melilotoside (1) from M. officinalis. cis-Melilotoside has previously been reported from several other plants such as Ajuga chamaecistus ssp. Tomentella and Mikania laevigata $[30,34]$.

Table 4. ${ }^{1} \mathrm{H}$ - and ${ }^{13} \mathrm{C}-\mathrm{NMR}$ data of compound $\mathbf{1}$ and from the literature.

\begin{tabular}{|c|c|c|c|c|c|}
\hline \multirow[t]{2}{*}{ Position } & \multirow[t]{2}{*}{ DEPT-135 } & \multicolumn{2}{|c|}{$\begin{array}{c}\mathbf{1} \\
{ }^{1} \mathrm{H}-\mathrm{NMR}\left(\mathrm{D}_{2} \mathrm{O}, 400 \mathrm{MHz}\right) \\
{ }^{13} \mathrm{C}-\mathrm{NMR}\left(\mathrm{D}_{2} \mathrm{O}, 100 \mathrm{MHz}\right)\end{array}$} & \multicolumn{2}{|c|}{\begin{tabular}{|c|} 
Literature [35] \\
${ }^{1} \mathrm{H}-\mathrm{NMR}$ (Methanol- $d_{4}, 500 \mathrm{MHz}$ ) \\
${ }^{13} \mathrm{C}-\mathrm{NMR}$ (Methanol- $d_{4}, 125 \mathrm{MHz}$ )
\end{tabular}} \\
\hline & & $\delta_{C}$ & $\delta_{H}$ & $\delta_{C}$ & $\delta_{H}$ \\
\hline 1 & $\mathrm{C}$ & 125.53 & - & 126.9 & - \\
\hline 2 & $\mathrm{C}$ & 153.81 & - & 156.7 & - \\
\hline 3 & $\mathrm{CH}$ & 115.36 & $7.12(d, J=8.0 \mathrm{~Hz}, 1 \mathrm{H})$ & 116.6 & $7.19(d, J=7.9 \mathrm{~Hz}, 1 \mathrm{H})$ \\
\hline 4 & $\mathrm{CH}$ & 130.56 & $7.30(d, J=8.0 \mathrm{~Hz}, 1 \mathrm{H})$ & 131.5 & $7.30(t, J=7.9 \mathrm{~Hz}, 1 \mathrm{H})$ \\
\hline 5 & $\mathrm{CH}$ & 122.85 & $7.03(t, J=8.0 \mathrm{~Hz}, 1 \mathrm{H})$ & 122.9 & $6.97(t, J=7.9 \mathrm{~Hz}, 1 \mathrm{H})$ \\
\hline 6 & $\mathrm{CH}$ & 130.09 & $7.34(d, J=8.0 \mathrm{~Hz}, 1 \mathrm{H})$ & 131.7 & $7.53(d, J=7.9 \mathrm{~Hz}, 1 \mathrm{H})$ \\
\hline 7 & $\mathrm{CH}$ & 137.14 & $7.09(d, J=12.0 \mathrm{~Hz}, 1 \mathrm{H})$ & 139.7 & $7.31(d, J=12.5 \mathrm{~Hz}, 1 \mathrm{H})$ \\
\hline 8 & $\mathrm{CH}$ & 122.02 & $6.05(d, J=12.0 \mathrm{~Hz}, 1 \mathrm{H})$ & 121.4 & $5.97(d, J=12.5 \mathrm{~Hz}, 1 \mathrm{H})$ \\
\hline 9 & $\mathrm{C}$ & 171.74 & - & 170.4 & - \\
\hline $1^{\prime}$ & $\mathrm{CH}$ & 100.41 & $5.05(d, J=7.2 \mathrm{~Hz}, 1 \mathrm{H})$ & 102.7 & $4.94(d, J=7.4 \mathrm{~Hz}, 1 \mathrm{H})$ \\
\hline $2^{\prime}$ & $\mathrm{CH}$ & 72.93 & $3.53(m, 1 \mathrm{H})$ & 75.0 & $3.49(m, 1 \mathrm{H})$ \\
\hline $3^{\prime}$ & $\mathrm{CH}$ & 76.12 & $3.53(m, 1 \mathrm{H})$ & 78.2 & $3.46(m, 1 \mathrm{H})$ \\
\hline $4^{\prime}$ & $\mathrm{CH}$ & 69.44 & $3.42(m, 1 \mathrm{H})$ & 71.4 & $3.40(m, 1 \mathrm{H})$ \\
\hline $5^{\prime}$ & $\mathrm{CH}$ & 75.71 & $3.53(m, 1 \mathrm{H})$ & 78.3 & $3.43(m, 1 \mathrm{H})$ \\
\hline $6^{\prime}$ & $\mathrm{CH}_{2}$ & 60.58 & $\begin{array}{l}3.84(d d, J=12.4,2,3 \mathrm{~Hz}, 1 \mathrm{H}) \\
3.67(d d, J=12.4,5.4 \mathrm{~Hz}, 1 \mathrm{H})\end{array}$ & 62.6 & $\begin{array}{l}3.87(m, 1 \mathrm{H}) \\
3.70(m, 1 \mathrm{H})\end{array}$ \\
\hline
\end{tabular}

Compound 2 was isolated from the $\mathrm{MeOH}$ extract of the seeds of $M$. officinalis as a white powder and has a melting point of $70-71{ }^{\circ} \mathrm{C}$. The $\mathrm{UV}-\mathrm{V}$ is spectrum of 2 in $\mathrm{MeOH}$ revealed an absorption maximum $\left(\lambda_{\max }\right)$ at 274 and the IR spectrum in $\mathrm{KBr}$ showed absorption bands at $1729,1288,1124 \mathrm{~cm}^{-1}$ due to the presence of an aromatic ring and an $\alpha, \beta$-unsaturated carbonyl carbon.

The ${ }^{13} \mathrm{C}-\mathrm{NMR}$ spectrum of 2 (Table 5) revealed the presence of 9 carbon atoms. The signal at $\delta 160.75$ is due to the carbonyl of a $\delta$-lactone. Besides, the two olefinic carbon signals at $\delta$ 116.94 and 143.38, and the six aromatic carbon signals at $\delta 116.76,118.86,124.41,127.84$, 131.83 and 154.11 indicated the presence of an aromatic ring and a double bond. In the ${ }^{1} \mathrm{H}-$ NMR spectrum of 2 (Table 5) the two olefinic proton doublets at $\delta 6.46(d, J=9.6 \mathrm{~Hz}, 1 \mathrm{H})$ and $7.74(d, J=9.6 \mathrm{~Hz}, 1 \mathrm{H})$ are attributable to $\mathrm{H}-3$ and $\mathrm{H}-4$ of the lactone nucleus, respectively. The signals at $\delta 7.34(m, 2 \mathrm{H}, \mathrm{H}-5$ and $\mathrm{H}-7)$ and $7.54(m, 2 \mathrm{H}, \mathrm{H}-6$ and $\mathrm{H}-8)$ revealed the presence of an ortho-substituted benzene ring. Compound 2 isthen identified as 1,2-benzopyrone (coumarin, Figure 2) by comparison of its spectral data with data in the literature [32]. Coumarin has 
previously been isolated from the $\mathrm{MeOH}$ extract of the aerial parts of M. Officinalis [4]. It was also found in many plants of the genus Melilotus.

Table 5. ${ }^{1} \mathrm{H}$ - and ${ }^{13} \mathrm{C}-\mathrm{NMR}$ data of compound $\mathbf{2}$ and from the literature.

\begin{tabular}{|c|c|c|c|c|c|}
\hline \multirow{2}{*}{ Position } & \multirow{2}{*}{ DEPT-135 } & \multicolumn{3}{|c|}{$\mathbf{2}$} & \multicolumn{2}{|c|}{$\begin{array}{c}\text { Literature [32] } \\
\end{array}$} & & ${ }^{13}$ C-NMR (Chloroform- $d, 400 \mathrm{MHz}$ ) & \multicolumn{2}{|c|}{${ }^{1} \mathrm{H}-\mathrm{NMR}$ (DMSO- $d_{6}, 300 \mathrm{MHz}$ ) } \\
\cline { 3 - 6 } & & $\delta_{C}$ & $\delta_{H}$ & $\delta_{C}$ & $\delta_{H}$ \\
\hline 2 & $\mathrm{C}$ & 160.75 & - & 159.84 & - \\
\hline 3 & $\mathrm{CH}$ & 116.94 & $6.46(d, J=9.6 \mathrm{~Hz}, 1 \mathrm{H})$ & 116.18 & $6.47(d, J=9.6 \mathrm{~Hz}, 1 \mathrm{H})$ \\
\hline 4 & $\mathrm{CH}$ & 143.38 & $7.74(d, J=9.6 \mathrm{~Hz}, 1 \mathrm{H})$ & 144.10 & $8.03(d, J=9.9 \mathrm{~Hz}, 1 \mathrm{H})$ \\
\hline 5 & $\mathrm{CH}$ & 127.84 & $7.34(m, 1 \mathrm{H})$ & 128.35 & $7.29(m, 1 \mathrm{H})$ \\
\hline 6 & $\mathrm{CH}$ & 124.41 & $7.54(m, 1 \mathrm{H})$ & 124.38 & $7.58(m, 1 \mathrm{H})$ \\
\hline 7 & $\mathrm{CH}$ & 131.83 & $7.34(m, 1 \mathrm{H})$ & 131.84 & $7.29(m, 1 \mathrm{H})$ \\
\hline 8 & $\mathrm{CH}$ & 116.76 & $7.54(m, 1 \mathrm{H})$ & 116.11 & $7.58(m, 1 \mathrm{H})$ \\
\hline 9 & $\mathrm{C}$ & 154.11 & - & 153.43 & - \\
\hline 10 & $\mathrm{C}$ & 118.86 & - & 118.6 & - \\
\hline
\end{tabular}

It was reported from ${ }^{14} \mathrm{C}$ feeding experiments that cis-melilotoside (1) is a biosynthetic precursor of coumarin (2) (Figure 2) [36, 37]. In the biosynthesis of coumarin (2), the trans isomer of $\beta$-glucoside-O-coumaric acid (3) undergoes isomerization to its cis isomer, cismelilotoside (1), which could then hydrolyze to coumarinic acid (4) which in turn lactonizes spontaneously to form coumarin (2).

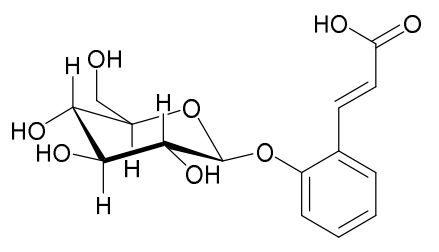

3

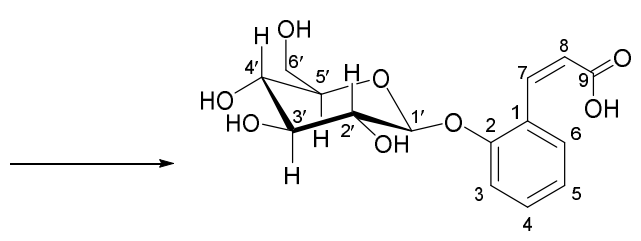

1<smiles>c1ccccc1</smiles><smiles>Cc1cc(=O)oc2ccccc12</smiles><smiles>O=C(O)/C=C\c1ccccc1O</smiles>

4

Figure 2. Proposed biosynthetic pathway of coumarin (2) [36, 37].

\section{- CONCLUSION}

In this work, the fatty acid composition of the $n$-hexane extract of the seeds of $M$. officinalis was determined using GC-MS. Quantifications of components in the $n$-hexane extract were made by using their relative area percentages and methyl palmitate external standards. Coumarin (2), 
which has been grouped among compounds that show hepatotoxicity [38], was detected in significant amount in the seed oil. Therefore, it may not be suitable to use the oil for cooking purposes just as it is. In order to use the oil for cooking purposes, the amount of coumarin (2) needs to be limited to tolerable daily intake (TDI) set by European Food Safety Authority (EFSA) which is $0.1 \mathrm{mg} / \mathrm{kg}$ body weight [39]. Phytochemical investigation of M. officinalis seeds resulted in the isolation of cis-melilotoside (1) and coumarin (2) by column chromatography over Sephadex LH-20 and preparative TLC techniques. The isolated compounds were then characterized by their NMR, UV-Vis, and FTIR spectra. Antioxidant activity of the $\mathrm{MeOH}$ extract of $M$. officinalis seeds was also evaluated which exhibited a $29.87 \%$ DPPH inhibition at concentration of $100 \mu \mathrm{g} / \mathrm{mL}$.

\section{REFERENCES}

1. Inga, H.; Sue, E. Flora of Ethiopia, Vol. 3, The National Herbarium, Biology Department, Addis Ababa University and The Department of Systematic Botany, Uppsala University: Addis Ababa, Ethiopia; 1989; p 245.

2. Udayama, M.; Kinjo, J.; Yoshida, N.; Nohara, T. A new oleanene glucuronide having a branched-chain sugar from Melilotus officinalis. Chem. Pharm. Bull. 1998, 46, 526-527.

3. Hamid, A.; Raina, A. Ethnobotanical uses of plants in and around Kanji Wildlife Sanctuary, north west Himalaya. Int. J. Sci. Res. 2014, 3, 538-545.

4. Kang, S.S.; Lim, C.-H.; Lee, S.Y. Soyasapogenols B and E from Melilotus officinalis. Arch. Pharm. Res. 1987, 10, 9-13.

5. Pleşca-Manea, L.; Pârvu, A.E.; Pârvu, M.; Taamaş, M.; Buia, R.; Puia, M. Effects of Melilotus officinalis on acute inflammation. Phytother. Res. 2002, 16, 316-319.

6. Pourmorad, F.; Hosseinimehr, S.; Shahabimajd, N. Antioxidant activity, phenol and flavonoid contents of some selected Iranian medicinal plants. Afr. J. Biotechnol. 2006, 5, 1142-1145.

7. Miliauskas, G.; Venskutonis, P.; Van Beek, T. Screening of radical scavenging activity of some medicinal and aromatic plant extracts. Food Chem. 2004, 85, 231-237.

8. Alamgeer, Z.; Qaisar, M.; Uttra, A.; Ahsan, H.; Khan, K.; Khan, I.; Saleem, M.; Khadijai, A. H.; Sharif, A.; Younis, W. Evaluation of hepatoprotective activity of Melilotus officinalis L. against paracetamol and carbon tetrachloride induced hepatic injury in mice. Acta. Pol. Pharm. Drug Res. 2017, 74, 903-909.

9. Kaur, S.; Sharma, A.; Bedi, P.M.S. Bioactivity guided isolation, characterization and quantification of an anxiolytic constituent - kaempferol, from Melilotus officinalis aerial parts. JBAPN 2017, 7, 379-390.

10. Trouillas, P.; Calliste, C.-A.; Allais, D.-P.; Simon, A.; Marfak, A.; Delage, C.; Duroux, J.-L. Antioxidant, anti-inflammatory and antiproliferative properties of sixteen water plant extracts used in the Limousin countryside as herbal teas. Food Chem. 2003, 80, 399-407.

11. Pastorino, G.; Marchetti, C.; Borghesi, B.; Cornara, L.; Ribulla, S.; Burlando, B. Biological activities of the legume crops Melilotus officinalis and Lespedeza capitata for skin care and pharmaceutical applications. Ind. Crops Prod. 2017, 96, 158-164.

12. Quijano-Celis, C.E.; Pino, J.A.; Morales, G. Chemical composition of the leaves essential oil of Melilotus officinalis (L.) Pallas from Colombia. J. Essent. Oil Bear. Plants 2010, 13, 313-315.

13. Gudzenko, A.V.; Vinogradov, B.A. Chemical composition of the essential oil from Melilotus officinalis (L.) Pall. World Appl. Sci. J. 2014, 29, 171-172.

14. Hirakawa, T.; Okawa, M.; Kinjo, J.; Nohara, T. A new oleanene glucuronide obtained from the aerial parts of Melilotus officinalis. Chem. Pharm. Bull. 2000, 48, 286-287.

15. Ilhan, M.; Ali, Z.; Khan, I. A.; Küpeli Akkol, E. A new isoflavane-4-ol derivative from Melilotus officinalis (L.) Pall. Nat. Prod. Res. 2019, 33, 1856-1861.

Bull. Chem. Soc. Ethiop. 2021, 35(1) 
16. Kang, S.S.; Lee, Y.S.; Lee, E.B. Saponins and flavonoid glycosides from yellow sweetclover. Arch. Pharm. Res. 1988, 11, 197-202.

17. Kang, S.S.; Lee, Y.-S.; Lee, E.-B. Isolation of azukisaponin V possessing leucocyte migration inhibitory activity from Melilotus officinalis. Kor. J. Pharmacogn. 1987, 18, 8993.

18. Kang, S.S.; Woo, W.S. Melilotigenin, a new sapogenin from Melilotus officinalis. J. Nat. Prod. 1988, 51, 335-338.

19. Khodakov, G.V. Triterpene and steroidal glycosides from the genus Melilotus and their genins. Chem. Nat. Compd. 2010, 46, 572-575.

20. Liu, Y.-T.; Gong, P.-H.; Xiao, F.-Q.; Shao, S.; Zhao, D.-Q.; Yan, M.-M.; Yang, X.-W. Chemical constituents and antioxidant, anti-Inflammatory and anti-tumor activities of Melilotus officinalis (Linn.) Pall. Molecules 2018, 23, 271-282.

21. Suhail, A.M.; Mohtasheem, M.; Azhar, I.; Hasan, M.; Bano, H. Chemical constituents from Melilotus officinalis. J. Basic Appl. Sci. 2008, 4, 89-94.

22. Sutiashvili, M.G.; Alaniya, M.D. Flavonoids of Melilotus officinalis. Chem. Nat. Compd. 1999, 35, 584-584.

23. Bakoglu, A.; Kiliç, Ö.; Kökten, K. Seed fatty acid composition of some Medicago L. and Melilotus L. (Fabaceae) taxa from Turkey. Anal. Chem. Lett. 2016, 6, 174-180.

24. Bubenchikova, V.N.; Drozdova, I.L. HPLC analysis of phenolic compounds in yellow sweet-clover. Pharm. Chem. J. 2004, 38, 195-196.

25. Dombrowicz, E.; Swiatek, L.; Guryn, R.; Zadernowski, R. Phenolic acids in herb Melilotus officinalis. Pharmazie 1991, 46, 156-157.

26. Christie, W.W. Advances in Lipid Methodology, Vol. 2, Oily Press: Dundee; 1993; p 69.

27. Blois, M.S. Antioxidant determinations by the use of a stable free radical. Nature 1958, 181, 1199-1200.

28. Bhuiyan, M.A.R.; Hoque, M.Z.; Hossain, S.J. Free radical scavenging activities of Zizyphus mauritiana. World J. Agric. Sci. 2009, 5, 318-322.

29. Calzada, F.; Velázquez, C.; Cedillo-Rivera, R.; Esquivel, B. Antiprotozoal activity of the constituents of Teloxys graveolens. Phytother. Res. 2003, 17, 731-732.

30. Sadati, N.; Jenett-Siems, K.; Siems, K.; Ardekania, M.R.S.; Hadjiakhoondi, A.; Akbarzadeh, T.; Ostad, S.N.; Khanavi, M. Major constituents and cytotoxic effects of Ajuga chamaecistus ssp. tomentella. Zeitschrift für Naturforschung C 2012, 67, 275-281.

31. Vasänge, M.; Liu, B.; Welch, C.J.; Rolfsen, W.; Bohlin, L. The flavonoid constituents of two Polypodium species (calaguala) and their effect on the elastase release in human neutrophils. Planta Med. 1997, 63, 511-517.

32. Ghareeb, M.A.; Saad, A.M.; Abdou, A.M.; Refahy, L.A.-G.; Ahmed, W.S. A new kaempferol glycoside with antioxidant activity from Chenopodium ambrosioides growing in Egypt. Orient. J. Chem. 2016, 32, 3053-3061.

33. Drake, E.N.; Brown, C.E. Application of nmr to biochemical kinetics. A laboratory experiment in physical biochemistry. J. Chem. Educ. 1977, 54, 124-127.

34. Ferreira, F.P.; de Oliveira, D.C.R. New constituents from Mikanialaevigata Shultz Bip. ex Baker. Tetrahedron Lett. 2010, 51, 6856-6859.

35. Canuto, K.M.; Silveira, E.R.; Bezerra, A.M.E. Phytochemical analysis of cultivated specimens of cumaru (Amburana Cearensis AC Smith). Quim. Nova 2010, 33, 662-666.

36. Kosuge, T.; Conn, E.E. The metabolism of aromatic compounds in higher plants III. The $\beta$ glucosides of coumaric, coumarinic, and melilotic acids. J. Biol. Chem. 1961, 236, 16171621.

37. Stoker, J.; Bellis, D. The biosynthesis of coumarin in Melilotus alba. J. Biol. Chem. 1962, 237, 2303-2305.

38. Lake, B.G.; Grasso, P. Comparison of the hepatotoxicity of coumarin in the rat, mouse, and syrian Hamster: A dose and time response study. Fundam. Appl. Toxicol. 1996, 34, 105-117. 
39. Mirjana, L.; Martina, J.; Drago, S.; Martina, P.; Vlatka, B.S.; Ines, C.; Maja, M. Coumarins in food and methods of their determination. Foods 2020, 9, 645-679. 